\title{
Myofibroblasts and the extracellular matrix network in post-myocardial infarction cardiac remodeling
}

\author{
Yonggang Ma $\cdot$ Lisandra E. de Castro Brás $\cdot$ Hiroe Toba $\cdot$ Rugmani Padmanabhan Iyer • \\ Michael E. Hall • Michael D. Winniford • Richard A. Lange • Suresh C. Tyagi • \\ Merry L. Lindsey
}

Received: 15 January 2014 / Accepted: 27 January 2014 / Published online: 13 February 2014

(C) The Author(s) 2014. This article is published with open access at Springerlink.com

\begin{abstract}
The cardiac extracellular matrix (ECM) fills the space between cells, supports tissue organization, and transduces mechanical, chemical, and biological signals to regulate homeostasis of the left ventricle (LV). Following myocardial infarction (MI), a multitude of ECM proteins are synthesized to replace myocyte loss and form a reparative scar. Activated
\end{abstract}

Y. Ma • L. E. de Castro Brás · H. Toba • R. P. Iyer • M. E. Hall • M. D. Winniford $\cdot$ R. A. Lange $\cdot$ M. L. Lindsey

San Antonio Cardiovascular Proteomics Center, San Antonio, TX, USA

Y. Ma $\cdot$ L. E. de Castro Brás $\cdot$ H. Toba $\cdot$ R. P. Iyer $\cdot$ M. E. Hall M. D. Winniford $\cdot$ M. L. Lindsey

Mississippi Center for Heart Research, Department of Physiology and Biophysics, University of Mississippi Medical Center, Jackson, MS, USA

M. E. Hall • M. D. Winniford

Cardiology Division, University of Mississippi Medical Center, Jackson, MS, USA

R. A. Lange

Department of Medicine, University of Texas Health Science Center at San Antonio, San Antonio, TX, USA

\section{S. C. Tyagi}

Department of Physiology and Biophysics, University of Louisville, Louisville, KY, USA

M. L. Lindsey

Research and Medicine Services, G.V. (Sonny) Montgomery

Veterans Affairs Medical Center, Jackson, MS, USA

M. L. Lindsey $(\bowtie)$

Department of Physiology and Biophysics, University of Mississippi

Medical Center, 2500 North State St., Jackson, MS 39216-4505,

USA

e-mail: mllindsey@umc.edu

H. Toba

Department of Clinical Pharmacology, Division of Pathological

Sciences, Kyoto Pharmaceutical University, Kyoto, Japan fibroblasts (myofibroblasts) are the primary source of ECM proteins, thus playing a key role in cardiac repair. A balanced turnover of ECM through regulation of synthesis by myofibroblasts and degradation by matrix metalloproteinases (MMPs) is critical for proper scar formation. In this review, we summarize the current literature on the roles of myofibroblasts, MMPs, and ECM proteins in MI-induced LV remodeling. In addition, we discuss future research directions that are needed to further elucidate the molecular mechanisms of ECM actions to optimize cardiac repair.

Keywords Extracellular matrix $\cdot$ MMP-9 $\cdot$ Myocardial infarction $\cdot$ Myofibroblast $\cdot$ Proteomics $\cdot$ Review

\section{Introduction}

Cardiovascular disease is an increasing burden worldwide, and myocardial infarction (MI) contributes significantly to morbidity and mortality. In-hospital survival for MI patients has greatly improved over the past three decades due to the introduction of reperfusion and other therapeutic strategies. However, as short-term survival after acute MI has improved, the incidence of heart failure post-MI has risen [34]. In response to MI, the left ventricle (LV) undergoes a series of changes in geometry and function, a process termed LV remodeling. Understanding the mechanisms of adverse LV remodeling is critical to our effort to improve long-term outcome after MI.

After $30 \mathrm{~min}$ of ischemia, cardiomyocytes undergo irreversible cell death, which induces an acute inflammatory response through upregulation of the complement pathway. Neutrophils and macrophages sequentially infiltrate the infarct region and release inflammatory mediators and matrix metalloproteinases (MMPs) to degrade extracellular matrix (ECM) and engulf tissue debris [70]. The LV has limited regenerative capacity, and a collagen-rich reparative scar is formed to replace the 
extensive loss of cardiomyocytes in the infarct zone [68]. Myofibroblasts are the major source of ECM in the scar. In response to inflammatory mediators, resident cardiac fibroblasts and other cell lineages are stimulated to differentiate into myofibroblasts, which results in abundant ECM synthesis and deposition [106]. The proper balance between ECM synthesis and degradation is critical for optimal infarct healing. Endogenous tissue inhibitors of metalloproteinases (TIMPs) block excessive MMP activity and play a key role in maintaining the balance between ECM synthesis and degradation. Excessive ECM accumulation increases wall stiffness and impairs compliance, leading to diastolic dysfunction, whereas inadequate ECM deposition and impaired collagen assembly facilitates progressive infarct wall thinning and infarct expansion that can lead to LV dilation, aneurysm formation, and rupture $[68,69]$.

ECM is composed of structural and nonstructural matricellular proteins, as well as a proteolytic system of MMPs and TIMPs [68]. After MI, an elevation in the production of structural ECM proteins generates an infarct scar, and matricellular proteins help to organize the ECM fibrillar structure as well as regulate the inflammatory and angiogenic responses. In this review, we summarize the current knowledge on the functions of myofibroblasts, MMPs, TIMPs, and specific ECM components in the MI-induced LV remodeling, as well as discuss future research directions to better understand these processes. Dissecting the mechanisms whereby fibroblasts and ECM molecules coordinate the post-MI remodeling response may identify potential interventions to stimulate an optimal infarct healing response.

\section{Cardiac fibroblasts and myofibroblasts}

Cardiac fibroblasts are the most numerous cell types in the heart, accounting for up to $70 \%$ of total cell numbers in the normal LV [91]. However, the role of fibroblasts has often been overlooked in favor of the more studied cardiomyocyte. Recent studies have focused on the complex and dynamic interaction between cardiac fibroblasts, cardiomyocytes, and leukocytes in the development of cardiovascular disease [8]. Under physiological conditions, cardiac fibroblasts provide a mechanical scaffold and coordinate systolic heart function. Additionally, myofibroblasts are the main producers of ECM proteins in the heart and function as local immune modulators [105].

\section{Cell origins and types}

The most common technique to identify cell source is the use of a fate map that represents the developmental history of each cell in the adult body [134]. Methods for fate mapping include labeling cells with dyes, creation of chimeric tissues from different species, detection of specific gene sequences (e.g., sex-mismatch transplantation), and the use of transgenic reporter systems (e.g., $\beta$-galactosidase) [47]. Cardiac fibroblasts have been tagged using transgenic mouse models, including the MHC-Cre skeletal muscle cell graft model that generated a subpopulation of skeletal-cardiac hybrid fibroblast cells, giving evidence for epithelial-mesenchymal transition origin [93, 135]. Even though the use of transgenic models to fate map cells is the current state of the art, it is limited since each model targets only one gene. A model where tagged cardiac fibroblasts from different sources could be visualized in real time would be ideal but is not yet feasible in adult mammals.

Fibroblasts are widely distributed within the body and display significant differences among organs and tissues. For example, fibroblasts from the atria respond differently to pathological stimuli compared with fibroblasts from the ventricle, denoting evidence of cellular diversity [7]. These differences result from the fact that cardiac fibroblasts can originate from different cellular sources depending on the stage of heart development and cellular context: homeostasis versus injury [33].

Following injury, myofibroblasts are induced by a variety of cell lineages and are the primary contributor of ECM. In addition to resident cardiac fibroblasts, myofibroblasts originate from bone marrow-derived fibrocytes, mesenchymal stem cells, epithelial/endothelial cells, pericytes, and monocytes (Fig. 1) [55]. Upon injury, resident cardiac fibroblasts are activated and differentiated into myofibroblasts by a series of inflammatory mediators and mechanical alterations [115]. Friendenstein and colleagues presented the first in vitro evidence for the bone marrow origin of fibroblasts about 40 years ago $[31,65]$. They cultured bone marrow cells in media with fetal bovine serum and identified the resulting colonies as fibroblasts. Circulating cardiac fibroblast progenitor cells derived from the bone marrow have recently been termed fibrocytes [115]. Mesenchymal stem cells have pluripotent differentiation potential and are capable of differentiating into myofibroblasts [10]. Another origin of myofibroblasts is the epithelial/endothelial-mesenchymal transition (EMT), which describes tissue generation of myofibroblasts originating from organ epithelium (epithelial cells) and endothelium (endothelial cells) [54]. Pericytes play an important role in microvessel formation, maturation, and stability. In response to injury,

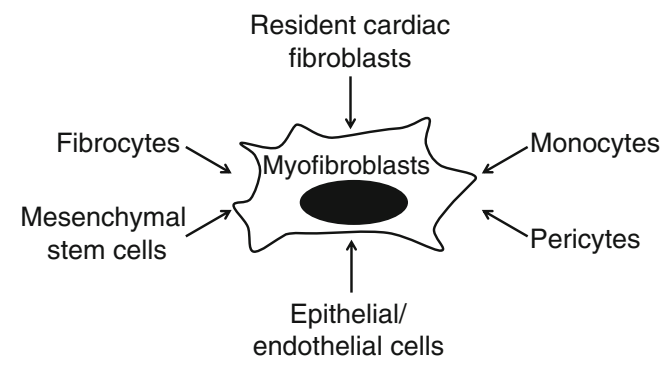

Fig. 1 Origins of cardiac myofibroblasts. Cardiac myofibroblasts originate from a wide array of cell sources, including resident cardiac fibroblasts, bone marrow-derived fibrocytes, mesenchymal stem cells, epithelial/endothelial cells, pericytes, and monocytes 
pericytes can also become myofibroblasts [28]. Very recently, Trial and colleagues showed that monocytes infiltrating the heart can differentiate into fibroblasts [112]. This demonstration of conversion between mature cells opens an exciting new direction for $\mathrm{LV}$ remodeling research.

\section{Myofibroblast activation and differentiation}

Myofibroblasts are essential for wound healing and have a contractile phenotype, sharing characteristics of smooth muscle cells [68]. This cell type is normally not present at high numbers in the healthy myocardium, but are a predominant cell type in the infarcted tissue after day 3 post-MI. Myofibroblasts express large amounts of $\alpha$-smooth muscle actin ( $\alpha$-SMA), vimentin, desmin, and fibronectin extra domain A (EDA) markers [5]. The most commonly used molecular marker for myofibroblasts is $\alpha$-SMA [41]. Expression of $\alpha$-SMA increases myofibroblast contractile activity over 2fold in vitro [39]. The mechanism behind this process is still unclear; however, the $\alpha$-SMA specific $\mathrm{N}$-terminal amino acid sequence AcEEED plays a central role in inducing cell contractibility. In vivo and in vitro studies show that delivery of the peptide AcEEED selectively inhibits $\alpha$-SMA expression and reduces myofibroblast contractile activity [40]. Uncontrolled proliferation and/or activation of myofibroblasts results in tissue fibrosis. Therefore, identifying the mechanisms of action of the peptide AcEEED may help to understand the mechanisms involved in tissue remodeling, particularly in conditions of pathological fibrosis.

Transforming growth factor (TGF)- $\beta$ is a major promoter of myofibroblast activation and differentiation. TGF- $\beta$ induces the expression of $\alpha$-SMA, modulates the expression of adhesive receptors, and enhances the synthesis of ECM molecules including collagen I and fibronectin EDA [43]. The pathway leading to TGF- $\beta$ activation has been extensively studied. Proteases including plasmin, MMP-2, and MMP-9 cleave latent TGF- $\beta$ to generate the active form [6]. Thrombospondin (TSP)-1 is also a key TGF- $\beta$ activator, which acts by disrupting the noncovalent bond between the latency-associated peptide and the TGF- $\beta$ molecule $[71,83]$. Active TGF- $\beta$ binds to TGF- $\beta$ receptor type II and results in phosphorylation of receptor-activated Smads. Phosphorylated Smads (Smads 2, 3, and 4) form heteromeric complexes that translocate into the nucleus and result in efficient TGF- $\beta$ signal transduction [86]. Activation of the Smad3 signaling pathway has been reported to stimulate ECM protein synthesis and TIMP upregulation in myofibroblasts [120].

The capability of TGF- $\beta$ to induce myofibroblast differentiation is regulated by matricellular and ECM proteins, including tenascin-C, periostin, TSP-1, connective tissue growth factor (CTGF), secreted protein acidic and rich in cysteine (SPARC), and fibronectin. Tenascin-C, a matricellular protein that is upregulated post-MI, promotes recruitment of myofibroblasts in the early stages of myocardial repair through stimulation of cell migration and differentiation [110]. Periostin promotes myofibroblast recruitment and collagen synthesis, and periostin null mice have increased rates of LV rupture post-MI due to reduced collagen deposition [87, 104]. TSP-1 has been associated with myofibroblast maturation and fibrogenesis in a model of pressure-overloaded heart [128]. CTGF enhances TGF- $\beta$-induced fibroblast differentiation into myofibroblasts [19]. SPARC deficiency results in impaired fibroblast activation and decreased ECM production post-MI, thus facilitating LV rupture [79]. Serini and colleagues showed that fibronectin EDA deposition precedes $\alpha$ SMA expression during granulation tissue evolution and during in vitro TGF- $\beta$ fibroblast stimulation and differentiation, with the degree of myofibroblast differentiation proportional to the levels of fibronectin EDA [102]. Moreover, a fibronectin EDA blocking antibody inhibits TGF- $\beta$ induced expression of $\alpha$-SMA and collagen I in cultured cardiac fibroblasts, implying that fibronectin EDA mediates TGF- $\beta$-induced fibroblast differentiation [102]. From these studies, it is clear that matricellular proteins regulate several aspects of myofibroblast function.

\section{Myofibroblast functions}

The myofibroblast has two main functions post-MI: provide mechanical strength to the scar by secreting new ECM proteins to replace the damaged myocardium and stimulating infarct contraction and produce factors that regulate the inflammatory and fibrotic responses. Myofibroblasts directly contact with ECM proteins through stress fibers at cellintegrin-matrix junction sites and with other cells via $N$ cadherin-type adherens junctions [38, 42]. These junctions increase myofibroblast contractility that is essential for structural integrity and support the new matrix to strengthen the infarct scar.

Post-MI, myofibroblasts migrate into the damaged tissue and synthesize new ECM. The activation stimuli come from pro-inflammatory cytokines and hormones, which are released by inflammatory and resident cells and from changes in the mechanical microenvironment [91, 111]. Following MI, cardiac fibroblasts respond to the loss of ECM integrity, increased mechanical stress, and increased levels of plateletderived growth factor by adopting a partially differentiated phenotype known as the proto-myofibroblast [111]. Subsequently, myofibroblasts enhance their proliferative and migratory rates, secrete ECM proteins, synthesize MMPs, and regulate expression of cytokines and growth factors, such as tumor necrosis factor- $\alpha$, interleukin (IL)- 1 , IL-6, and TGF- $\beta$ [91].

In summary, myofibroblasts embody a unique, yet developmentally diverse, population of cells that play a major role in post-MI LV remodeling. Enhanced understanding of the 
cell source and the myofibroblast regulatory mechanisms can facilitate the generation of therapeutic targets for this multifunctional cell type to optimize infarct scar formation and prevent progression to heart failure.

\section{MMPs}

MMPs are a group of proteolytic enzymes consisting of 25 known members. These proteins are generally released in their zymogen form, with the exception of MMP-11 and MMP-28 [46]. Structurally, the MMPs typically consist of four domains, which include a pro-domain, a catalytic domain, a hinge region, and a hemopexin domain [121]. MMP-2 and MMP-9 also have a fibronectin type II-like domain inserted into the catalytic domain that facilitates collagen cleavage [121]. With the exception of MMP-23, these enzymes are activated by a cysteine switch mechanism; disassociation of cystein-73 residue from zinc atom is required for exposure of the catalytic site, which is the switch that leads to the activation of the MMP [117, 121].

MMPs have been categorized into five groups based loosely on in vitro substrate specificity and localization: collagenases, gelatinases, stromelysins, matrilysins, and membrane type MMPs [89]. The role of MMPs in cardiac repair has been a focus of our group $[46,63]$. In this review, we will focus on the role of MMP-1, MMP-2, MMP-3, MMP-7, MMP-8, MMP-9, MMP-13, MMP-14, and MMP-28, which are the MMPs that have been evaluated post-MI (Table 1).

\section{MMP-1}

MMP-1 (fibroblast collagenase or collagenase-1) was the first MMP discovered and named in 1966 [85]. MMP-1 has latent $(57 / 52 \mathrm{kDa})$ and active (49/37 kDa) forms. MMP-1 can be expressed myocytes, macrophages, and fibroblasts [63]. Rodents do not express the same MMP-1 gene expressed by humans but rather have homologous forms MMP-1a and MMP-1b. MMP-1 cleaves collagen, gelatin, laminin, as well as non-ECM substrates such as complement C1q, IL-1 $\beta$, and tumor necrosis factor- $\alpha[63,121]$. MMP-1 activity in the infarct area has been reported to increase 2 days after MI, peaking at day 7 [17]. This expression pattern indicates that MMP-1 may regulate the late inflammatory response and ECM turnover. In patients with acute MI, plasma MMP-1 levels are positively associated with LV dysfunction and dilation, implying that increased collagenolytic activity facilitates impairment of LV function [88].

Table 1 MMPs and TIMPs in the MI setting

\begin{tabular}{|c|c|c|c|}
\hline MMP & $\begin{array}{l}\text { Post-MI } \\
\text { expression }\end{array}$ & Cellular source & Roles \\
\hline 1 & $\uparrow$ & Myocyte, macrophage, and fibroblast & Predicts LV dysfunction and dilation in MI patients \\
\hline 2 & $\uparrow$ & $\begin{array}{l}\text { Myocyte, fibroblast, myofibroblast, vascular smooth } \\
\text { muscle cells, and endothelial cell }\end{array}$ & $\downarrow$ survival, $\uparrow \mathrm{LV}$ rupture, and $\uparrow$ macrophage infiltration \\
\hline 3 & $\uparrow$ & Myocyte, fibroblast, and macrophage & $\begin{array}{l}\text { Correlates with LV dysfunction and mortality in MI patients, and } \\
\text { activates MMP-1, MMP-3, MMP-7, MMP-8, MMP-9, and } \\
\text { MMP-13 }\end{array}$ \\
\hline 7 & $\uparrow$ & Myocyte and macrophage & $\begin{array}{l}\downarrow \text { survival, } \downarrow \text { conduction velocity, and activates MMP-1, } \\
\text { MMP- } 2, \text { MMP- } 7 \text {, and MMP-9 }\end{array}$ \\
\hline 8 & $\uparrow$ & Neutrophil and macrophage & $\uparrow L V$ rupture, $\uparrow$ neutrophil infiltration, and degrades collagen \\
\hline 9 & $\uparrow$ & $\begin{array}{l}\text { Myocyte, fibroblast, neutrophil, macrophage, vascular } \\
\text { smooth muscle cell, and endothelial cell }\end{array}$ & $\begin{array}{l}\uparrow L V \text { dilation, } \downarrow / \uparrow L V \text { function, } \uparrow / \downarrow \text { inflammation, and } \uparrow \text { collagen } \\
\text { deposition }\end{array}$ \\
\hline 13 & $\uparrow$ & Fibroblast and macrophage & Activates MMP-9 \\
\hline 14 & $\uparrow$ & Myocyte, fibroblast, and myofibroblast & $\begin{array}{l}\downarrow \text { LV function, } \downarrow \text { survival, } \uparrow \text { fibrobsis, and activates MMP- } 2 \text { and } \\
\quad \text { MMP-13 }\end{array}$ \\
\hline 28 & $\begin{array}{l}\downarrow \text { in myocyte } \uparrow \text { in } \\
\text { macrophage }\end{array}$ & Myocyte and macrophage & $\begin{array}{c}\uparrow \mathrm{LV} \text { function, } \downarrow \text { LV rupture, } \downarrow \text { mortality, } \uparrow \mathrm{M} 2 \text { macrophage } \\
\text { polarization, and } \uparrow \text { collagen deposition and cross-linking }\end{array}$ \\
\hline \multicolumn{4}{|c|}{ TIMPs } \\
\hline 1 & $\uparrow$ & Myocyte and fibroblast & $\downarrow$ LV dilation \\
\hline 2 & $\uparrow$ & Fibroblast & $\begin{array}{l}\downarrow \text { LV dilation, } \uparrow \text { LV function, } \downarrow \text { infarct size, } \downarrow \text { inflammation, and } \\
\downarrow \downarrow \text { collagen disorganization }\end{array}$ \\
\hline 3 & $\downarrow$ & Fibroblast & $\begin{array}{l}\downarrow \text { LV dilation, } \uparrow \text { LV function, } \downarrow \text { LV rupture, } \downarrow \text { mortality, } \downarrow \text { infarct } \\
\text { size, } \uparrow \text { myofibroblast number, } \uparrow \text { collagen deposition, and } \downarrow \\
\text { MMP activity }\end{array}$ \\
\hline 4 & $\downarrow$ & Myocyte & $\downarrow$ LV rupture and $\downarrow$ mortality \\
\hline
\end{tabular}

MMPs matrix metalloproteinases, TIMPs tissue inhibitors of metalloproteinases, $M I$ myocardial infarction, $L V$ left ventricle 


\section{MMP-2}

MMP-2 (gelatinase A or $72 \mathrm{kDa}$ gelatinase) has a $72-\mathrm{kDa}$ latent and a 66/62-kDa active form [46]. MMP-2 is expressed by myocytes, fibroblasts, myofibroblasts, vascular smooth muscle cells, and endothelial cells [63]. Substrates for MMP-2 include both extracellular and intracellar proteins, including aggrecan, citrate synthase, elastin, fibronectin, fusion protein, IL-1 $\beta$, prolysyl oxidase, and other MMPs such as MMP-1, MMP-9, and MMP-13 [46]. Myosin light chain and troponin I are intracellular substrates for MMP-2 and highlight the interaction between some MMPs and cardiomyocytes [63, 98]. In animal studies, MMP-2 activity peaks by day 7 and declines to normal levels by day 14 after MI in the LV infarct area [63]. MMP-2 null mice subjected to MI have reduced macrophage infiltration in the infarct region, a lower rate of LV rupture, and improved survival in comparison to wild type mice [76]. This suggests a role for MMP-2 in regulating the entry of inflammatory cells in the infarcted area post-MI. Reduced ECM degradation in the absence of MMP2 may explain the reduced rupture phenotype observed in MMP-2 null mice. In humans, post-MI plasma MMP-2 levels were surprisingly inversely correlated with LV volumes, and a larger cohort study is warranted before these results are interpreted [107].

\section{MMP-3}

MMP-3 (stromelysin-1) has 59/57 kDa latent and $48 \mathrm{kDa}$ active forms. MMP-3 has casein and proteoglycan degrading properties and is expressed by myocytes, fibroblasts, and macrophages [63, 121]. MMP-3 activates MMP-1, MMP-3, MMP-7, MMP-8, MMP-9, and MMP-13, indicating crosstalk within the family members [121]. MMP-3 increases within 3 days post-MI in rats and declines over the next 14 days [64, 95]. In acute MI patients, plasma MMP-3 levels are positively associated with patient age and sex (higher in male patients), creatinine levels, and hypertension, but negatively correlate with LV ejection fraction [51]. As a result, MMP-3 has been suggested to be an independent predictor of LV systolic dysfunction and mortality in MI patients [51].

\section{MMP-7}

MMP-7 (matrilysin) is the smallest MMP, with $28 \mathrm{kDa}$ latent and $19 \mathrm{kDa}$ active forms. It is mainly expressed by the myocyte and macrophage. MMP-7 cleaves several ECM proteins and primarily activates MMP-1, MMP-2, MMP-8, and MMP-9 [121]. Post-MI, MMP-7 increases robustly in macrophages [121]. Our lab showed that MMP-7 deficiency improves mouse survival post-MI, but not by attenuating LV dilation $[60,63]$. Interestingly, MMP-7 deficiency protected mice from reduced conduction velocity, and MMP-7 was shown to directly bind and process connexin-43. Using a proteomic strategy, we identified fibronectin and tenascin-C as additional in vivo MMP-7 substrates in the infarcted LV [15]. In addition, MMP-7 may indirectly regulate the expression of peroxiredoxin-1, peroxiredoxin-2, and peroxiredoxin3 through nonenzymatic mechanisms [15].

\section{MMP-8}

MMP-8 has $64 \mathrm{kDa}$ latent and $58 \mathrm{kDa}$ active forms. Although originally named neutrophil collagenase, MMP-8 is actually secreted by both neutrophils and macrophages [63]. MMP-8 cleaves fibrillar collagens by binding collagen type I $\alpha 1$ and $\alpha 2$ chains, thus promoting cell migration [59]. MMP-8 mRNA increases as early as $6 \mathrm{~h}$. after MI. MMP-8 protein levels increase 2 weeks post-MI at both border and infarcted regions, and persist through 4 months, indicating its involvement in the early and late remodeling responses [90]. MMP-8 levels are higher in patients with LV rupture than those without rupture post-MI, indicating that MMP-8 may promote infarct rupture in humans by degrading collagen [116].

\section{MMP-9}

MMP-9 (gelatinase B or $92 \mathrm{kDa}$ gelatinase) is one of the first MMPs found to be expressed in infiltrating neutrophils and macrophages present in the infarct area [46, 70]. MMP-9 is also expressed by myocytes, fibroblasts, vascular smooth muscle cells, and endothelial cells- although at log-fold lower amounts compared with the infiltrating leukocytes [129]. In humans, MMP-9 has $92 \mathrm{kDa}$ latent and $88 \mathrm{kDa}$ active forms. In mice, MMP-9 has $105 \mathrm{kDa}$ latent and $95 \mathrm{kDa}$ active forms. MMP-9 is known to degrade a variety of proteins, including aggrecan, collagen, elastin, fibronectin, galectin-3, IL-1 $\beta$, laminin, SPARC, as well as activate TGF- $\beta 1$ by processing the latent TGF- $\beta$ binding protein $[46,133]$. An increase in MMP-9 levels correlates with the development of LV dysfunction [3]. Targeted deletion of the MMP-9 gene in mice leads to decreased collagen accumulation and attenuated LV dilation post-MI [24]. Of note, overexpression of MMP-9 only in macrophages also leads to beneficial effects post-MI (e.g. attenuated inflammatory response and improved LV function), suggesting various levels of regulation of post-MI healing process by MMP-9, depending on cell source and timing of expression [132].

\section{MMP-13}

MMP-13 (collagenase-3) has $60 \mathrm{kDa}$ latent and $48 \mathrm{kDa}$ active forms. Fibroblasts and macrophages are reported to express MMP-13 [46, 63]. MMP-13 mRNA amounts remain stable following MI through 16 weeks in the rat, but MMP-13 activity increases $72 \mathrm{~h}$. post-MI, indicating that MMP-13 
activity can increase without affecting gene expression [46]. Not much is known about MMP-13 functions, mechanism of action, or how it affects LV remodeling post-MI; however, it is known to stimulate MMP-9 activation [46, 121].

\section{MMP-14}

MMP-14 (membrane type 1 MMP; MT-1 MMP) has $65 \mathrm{kDa}$ latent and $54 / 45 / 40 \mathrm{kDa}$ active forms [63]. MMP-14 is expressed by cardiomyocytes, fibroblasts, and myofibroblasts. It cleaves collagen, fibronectin, gelatin, and can activate MMP-2 and MMP-13 [121]. MMP-14 increases 20 -fold at 3 days post-MI and 50-fold at 16 days post-MI in non-infarcted LV regions, indicating critical roles in both early and late remodeling events $[18,61,63]$. Furthermore, in animal studies the increase in MMP-14 post-MI is associated with significant cardiac fibrosis, reduced LV function, and lower survival [63].

\section{MMP-28}

MMP-28 (epilysin) is the newest identified member of the MMP family and was first cloned in 2001 [67]. The furin-like proprotein convertase processes the $58 \mathrm{kDa}$ pro-form of MMP-28 to its $48 \mathrm{kDa}$ active form, which is then secreted into the extracellular environment [69]. The 3 known substrates for MMP-28 are casein, Nogo-A (a myelin component), and neural cell adhesion molecule-1 [73, 121]. MMP28 is highly expressed in the normal heart, suggesting roles in normal tissue homeostasis. However, MMP-28 null mice do not show an abnormal heart phenotype in the unstressed setting [69]. We have recently shown that MMP-28 derived from macrophages increases at 5 days post-MI, although total levels of the protein in the infarct decrease due to the loss of myocytes [69]. MMP-28 deletion worsens LV dysfunction and mortality as a result of increased cardiac rupture rate, which is strongly associated with impaired M2 macrophage activation and ECM deposition [69]. This study introduces the idea that not every MMP is detrimental and reinforces the concept that selective MMP inhibitors are warranted to inhibit individual MMPs.

\section{TIMPs}

TIMPs are potent endogenous inhibitors of MMP activity and include four homologous members: TIMP-1, TIMP-2, TIMP3, and TIMP-4. TIMPs play important roles in LV remodeling post-MI by directly inhibiting MMP activity and indirectly regulating remodeling processes (Table 1).
TIMP-1

TIMP-1, a 29-kDa glycoprotein, is secreted by myocytes and fibroblasts. TIMP-1 mRNA increases in the infarct region within $6 \mathrm{~h}$. following MI and declines after 2 days with no detectable alterations in regions remote from the infarct [17, 63]. Compared with wild-type counterparts, TIMP-1 knockout mice show larger LV volumes, which can be reversed by MMP inhibition [44]. This indicates that TIMP-1-dependent beneficial effects are mediated by inhibiting MMP activity.

\section{TIMP-2}

TIMP-2 (28 kDa), which is primarily secreted by fibroblasts, is highly expressed in the normal myocardium. In addition to suppressing MMP activity, TIMP-2 is the only TIMP that is required for cell surface activation of pro-MMP2, suggesting both anti- and pro-activating roles [49]. TIMP-2 mRNA increases post-MI whereas the protein level does not undergo major change. Kandalam et al showed that the absence of TIMP-2 post-MI was associated with greater infarct expansion and LV dilation, worse LV dysfunction, and more severe inflammation and collagen disarray [49]. This could be mainly attributed to its inhibitory action on MMP-14. Therefore, TIMP-2 supplementation may provide a potential strategy in attenuating LV remodeling post-MI.

\section{TIMP-3}

TIMP-3 (24 kDa) is ECM bound and has been shown to be a powerful inhibitor of all MMPs. TIMP-3 is highly expressed in the normal heart (secreted by fibroblasts). TIMP-3 protein levels decrease in both animals and patients with MI. Post-MI, TIMP-3 deletion has been demonstrated to increase mortality as a result of enhanced cardiac rupture, greater infarct expansion, exacerbated LV dilation, and worse LV dysfunction [48]. TIMP-3 null mice subjected to MI also showed reduced collagen synthesis, disorganized collagen deposition, decreased myofibroblast number in the infarct area, and increased MMP activity [37, 48]. MMP inhibition reverses the effects observed in the TIMP-3 null mice. Thus, proteolytic activity early post-MI is a promoting factor for subsequent adverse LV remodeling and dysfunction, and timing of intervention to improve the LV response to MI may be critical in producing a beneficial outcome [48].

\section{TIMP-4}

In addition to having a $24-\mathrm{kDa}$ form, TIMP-4 has a $28-\mathrm{kDa}$ glycosylated form reported to be expressed by cardiomyocytes [63]. Unlike other TIMPs, TIMP-4 mRNA does not increase post-MI but protein levels reportedly decrease in weeks 1 and 4 post-MI $[9,118]$. Similarly to other 
TIMPs, TIMP-4 deletion results in increased LV rupture and mortality, which can be prevented by MMP inhibition [53]. Plasma TIMP-4 levels, but not TIMP-1 or TIMP-2 plasma levels, has been suggested to predict LV remodeling in MI patients [124].

Taken together, studies clearly show the importance of MMPs and TIMPs post-MI and demonstrate that their protein and activity levels change during different phases of the wound healing process to regulate LV remodeling. Additional studies that explore the temporal and spatial patterns of MMP and TIMP expression will expand our understanding of the mechanisms of LV remodeling.

\section{Structural ECM}

Fibrillar collagens, fibronectin, and laminins comprise the structural component of the ECM, which is important in maintaining architecture and preserving normal LV function [68]. Several functional domains within structural ECM or ECM-derived fragments serve critical roles in LV remodeling in the MI setting (Table 2) [68].

\section{Collagens}

Collagens are the most abundant ECM proteins in the LV; and of 28 subtypes, collagen type I is the most abundant [12]. Following MI, collagen types I, III, IV, V, and VI increase in the infarct region, covering approximately 30 and $60 \%$ of the infarct area at days 7 and 21 post-MI, respectively [62, 103]. In particular, collagen types I and III are major components of the myocardium scar [103]. The cardiac fibroblast is the major source of collagens in the post-MI setting. Proper collagen accumulation and assembly is essential for preventing progressive LV dilation post-MI. Collagen proteolysis post-MI is regulated by multiple MMPs that have collagenolytic activity, including MMP-1, MMP-2, MMP-8, MMP-9, MMP-13, and MMP-14. The role of collagen peptides that are generated by MMP activity during LV remodeling, however, has not fully clarified.

Circulating collagen peptides are commonly used as cardiac biomarkers of myocardial fibrosis and as a prognosticator of cardiac function. Collagens are synthesized as procollagen forms, which are secreted into the interstitial space where they undergo cleavage of their end-terminal propeptide sequences to enable collagen fiber formation [123]. The collagen terminal propeptides (e.g., amino $(N)$-propeptide and carboxy $(C)$ propeptide) are released into the circulation by the action of specific procollagen $N$ - and $C$-proteinases [122]. The most commonly used biomarker for quantification of collagen type I synthesis is its $100 \mathrm{kDa}$ C-terminal propeptide, with serum levels positively associated with diastolic dysfunction [74]. The N-terminal propeptide of collagen type III is a $42-\mathrm{kDa}$
Table 2 Roles of ECM proteins increased post-MI

\begin{tabular}{|c|c|}
\hline Name & Roles \\
\hline \multicolumn{2}{|l|}{ Structural ECM } \\
\hline Collagen I and III & $\begin{array}{l}\text { Scar components and correlates with diastolic } \\
\text { dysfunction and mortality risk }\end{array}$ \\
\hline Collagen IV and V & Basement membrane components \\
\hline Collagen VI & $\begin{array}{l}\downarrow L V \text { function, } \uparrow \text { apoptosis, and } \uparrow \text { collagen } \\
\quad \text { deposition }\end{array}$ \\
\hline Fibronectin EDA & $\begin{array}{c}\uparrow \text { LV dilation, } \downarrow \text { LV function, } \uparrow \text { inflammation, } \uparrow \\
\text { MMP activity, and } \uparrow \text { myofibroblast numbers }\end{array}$ \\
\hline Laminin & $\begin{array}{l}\text { Basement membrane component and negative } \\
\text { correlation with LV function }\end{array}$ \\
\hline \multicolumn{2}{|l|}{ Matricellular proteins } \\
\hline $\mathrm{CCN}-1$ & $\begin{array}{l}\uparrow \text { apoptosis, } \downarrow \text { inflammation, and } \downarrow \text { fibrosis in } \\
\text { other models }\end{array}$ \\
\hline $\mathrm{CCN}-2 / \mathrm{CTGF}$ & $\downarrow$ infarct size in an ischemia/reperfusion model \\
\hline CCN-4/WISP1 & $\begin{array}{l}\downarrow \text { myocyte apoptosis, } \uparrow \text { hypertrophy, and } \uparrow \\
\text { fibroblast proliferation (in vitro) }\end{array}$ \\
\hline Osteopontin & $\begin{array}{l}\downarrow \text { LV remodeling, } \downarrow \text { LV dilation, } \uparrow \text { collagen } \\
\text { deposition, and } \uparrow \text { angiogenesis }\end{array}$ \\
\hline Periostin & $\begin{array}{l}\uparrow L V \text { function, } \downarrow \text { LV rupture, } \downarrow \text { fibrosis, and } \uparrow \\
\text { regeneration }\end{array}$ \\
\hline SPARC & $\begin{array}{l}\uparrow \mathrm{LV} \text { function, } \downarrow \text { LV rupture, } \downarrow \text { mortality, } \uparrow \\
\text { macrophage infiltration, and } \uparrow \text { scar } \\
\text { organization }\end{array}$ \\
\hline Tenascin-C & $\begin{array}{l}\uparrow \mathrm{LV} \text { remodeling, } \downarrow \text { LV function, } \uparrow \text { fibrosis, and } \uparrow \\
\text { fibroblast function }\end{array}$ \\
\hline Thrombospondin-1 & $\begin{array}{l}\downarrow \text { LV remodeling, } \uparrow \text { LV function, and } \downarrow \\
\text { inflammation }\end{array}$ \\
\hline \multicolumn{2}{|c|}{ Proteins with matricellular functions } \\
\hline Galectin-3 & $\begin{array}{l}\text { Positive correlation with infarct size, heart } \\
\text { failure, and 30-day mortality }\end{array}$ \\
\hline Biglycan & $\begin{array}{l}\downarrow L V \text { dilation, } \uparrow \text { LV function, } \downarrow \text { LV rupture, } \downarrow \\
\quad \text { mortality, } \uparrow \text { LV tensile strength, and } \uparrow \text { scar } \\
\quad \text { organization }\end{array}$ \\
\hline Decorin & $\begin{array}{l}\downarrow \text { LV dilation, } \uparrow \text { LV function, } \downarrow \text { infarct size, } \downarrow \\
\text { hypertrophy, and } \uparrow \text { scar organization }\end{array}$ \\
\hline Syndecan-1 & $\begin{array}{c}\downarrow \text { LV remodeling, } \uparrow \text { LV function, } \downarrow \text { inflammation, } \\
\downarrow \text { MMP activity, and } \uparrow \text { scar quality }\end{array}$ \\
\hline Syndecan-4 & $\begin{array}{l}\uparrow \mathrm{LV} \text { function, } \downarrow \text { LV rupture, } \downarrow \text { mortality, } \uparrow \\
\text { inflammation, and } \uparrow \text { ECM deposition }\end{array}$ \\
\hline Vitronectin & Positive correlation with MI severity \\
\hline
\end{tabular}

$E C M$ extracellular matrix, $M I$ myocardial infarction, $L V$ left ventricle, $C T G F$ connective tissue growth factor, SPARC secreted protein acidic and rich in cysteine

peptide that is widely used as a marker for collagen type III synthesis [97]. Elevated serum levels of this peptide have been positively correlated with increased mortality risk and heart failure [16].

The non-fibrillar collagens, such as collagen types IV and $\mathrm{V}$, organize the basement membrane structure. Collagen type IV levels increase in both infarcted and non-infarcted area post-MI [103]. Collagen type VI increases in the infarcted area 
within days post-MI, and then accumulates in both infarct and non-infarct area [66]. Surprisingly, absence of collagen type VI improves LV function, structure, and remodeling after MI by inhibiting apoptosis and collagen accumulation [66]. This indicates that collagens not only constitute the major components of the scar, but also regulate cardiac healing.

\section{Fibronectin}

Fibronectin is a multifunctional adhesive glycoprotein produced by fibroblasts, macrophages, and endothelial cells in response to tissue injury. Fibronectin regulates cell shape and movement. For example, fibronectin guides macrophages into wound areas. Fibronectin contains an alternatively spliced exon encoding type III repeat EDA that is only expressed during development or after injury [68]. EDA can bind both toll-like receptor-2 and toll-like receptor-4 and activate monocytes in vitro [100]. EDA injection into murine joints activates nuclear factor- $\mathrm{kB}$, resulting in enhancement of the inflammatory response [35]. EDA also regulates cell adhesion and proliferation and stimulates TGF- $\beta$ pathway, which leads to generation of the myofibroblast phenotype [58, 102]. Interestingly, EDA-null mice with MI exhibit less LV dilation and better LV function compared with wild-type mice [2]. EDAnull mice also showed the reduced inflammation, MMP-2 and MMP-9 activities, and myofibroblast differentiation. These results suggest that EDA plays a critical role in adverse LV remodeling post-MI. Fibronectin also contains the extra domain $\mathrm{B}$ (EDB), which is expressed during embryogenesis [32]. Although the role of EDB in the MI setting has not been evaluated, EDB is highly expressed in normal tissue during angiogenesis, suggesting a role for EDB during LV remodeling following MI. Recently, using a proteomic approach, we showed that fibronectin is an in vivo substrate of both MMP-7 and MMP-9 $[15,133]$. These findings expand our understanding of protective mechanisms when MMP-7 or MMP-9 is deleted in the MI setting.

\section{Laminins}

Laminins are essential components of basement membranes and are composed of $\alpha, \beta$, and $\gamma$ chains. At least 15 laminin isoforms have been identified to date. Laminin is the first ECM to appear in the embryo. Laminin anchors cells to the ECM and can bind to multiple receptor proteins, such as collagen type IV, dystroglycan, entactin, heparin, heparin sulfate, integrins, and syndecans [108]. Laminin levels increase in the infarct area at day 3 post-MI and peak at days 7 to11 [82]. In the MI setting, laminin is detected throughout the infarct region, and this wide distribution suggests that the role of laminin post-MI exceeds the maintenance of basement membranes [82]. The expression pattern of laminin post-MI is similar to that of collagen type IV [82]. Serum concentrations of laminin and collagen type IV in acute MI patients are higher than in patients with stable or no coronary artery disease [22], and correlate with the severity of LV dysfunction [22]. This suggests that serum laminin and collagen type IV levels may be surrogate markers of ECM remodeling post-MI.

\section{Matricellular proteins}

Matricellular proteins are a family of nonstructural matrix proteins that are capable of regulating a variety of biological functions by interacting with cell surface receptors, growth factors, proteases, and structural matrix [4]. Under normal conditions, matricellular proteins are generally present at very low expression levels. Following injury (e.g., MI), their expression increases substantially, implying a role in the repair response [68]. Matricellular proteins consist of CCN family members, osteopontin, periostin, SPARC, tenascins, and TSPs. Their roles in MI-induced LV remodeling have been extensively reviewed by several groups (summarized in Table 2) [29, 68]. Some proteins, such as galectins, small leucine-rich proteoglycans (SLRPs), syndecans, and vitronectin, share matricellular structure and/or functions, but have not been assigned to the family of matricellur proteins. In the following section, we will summarize current knowledge on their functions in MI-induced LV remodeling.

\section{Galectin-3}

Galectins are composed of a family of evolutionarily conserved glycan-binding proteins and can bind to the carbohydrate portion of glycoproteins and glycolipids in the cell surface. Based on their structure and the number of carbohydrate recognition domain, galectins have been divided into three groups: (1) prototype galectins: galectin-1, galectin-2, galectin-5, galectin-7, galectin-10, galectin-11, galectin-13, and galectin-14; (2) tandem-repeat galectins: galectin-4, galectin-6, galectin-8, galectin-9, and galectin-12; and (3) chimera galectin-3 [131].

Among those, galectin-3 is the most widely investigated member associated with cardiovascular disease. Galectin-3 is a $\beta$-galactoside binding lectin primarily expressed by activated macrophages and serves as a novel marker for inflammation and fibrosis [25]. Weir and colleagues reported that plasma galectin-3 levels increased significantly following MI (mean, $46 \mathrm{~h}$ after MI) and was positively associated with remodeling parameters in patients with supra-median baseline LV ejection fraction $(>49.2 \%)$ but not when LV ejection fraction was $\leq 49.2 \%$ [125].

In patients undergoing primary percutaneous coronary intervention for ST elevation MI, circulating galectin-3 levels were significantly higher than in healthy subjects, and 
elevated circulating level of galectin-3 was the strongest independent predictor of the combined 30-day major adverse clinical outcome (defined as advanced congestive heart failure or 30-day mortality) [114]. Elevated galectin-3 levels 4 months after acute MI are associated with larger infarct sizes, lower global myocardial function as well as with higher concentrations of NT-pro brain natriuretic peptide, highlighting the potential of galectin-3 as a biomarker of adverse remodeling after acute MI [78]. In patients with first MI treated with primary percutaneous coronary intervention, serum galectin3 levels were an independent predictor for re-infarction [109]. These studies demonstrate the utility of galectin-3 in assessing late phases of LV remodeling after MI.

\section{Small leucine-rich proteoglycans}

The SLRPs are a family of SLRPs that are divided into five classes based on homologies at both the genomic and protein levels [14]. SLRPs have a central domain termed tandem leucine-rich repeats, which can bind to innate immune receptors. SLRPs act as endogenous danger signals, known as damage-associated molecular patterns, which activate the innate immune system and regulate sterile inflammationassociated disease [30]. Of the ten family members, biglycan and decorin are well investigated regarding their roles in cardiovascular disease. Biglycan and decorin bind to collagen types I, II, III, and VI, and regulate collagen fibrillogenesis and fibril diameter [23]. The decorin binding site on collagen type I has been identified near the $\mathrm{C}$ terminus, very close to one of the major intermolecular cross-linking sites of collagen heterotrimers [50].

Post-MI, cardiac biglycan expression is significantly upregulated peaking at day 7 , denoting a possible role in cardiac repair [127]. In animal studies, biglycan deficiency led to increased mortality rates after MI as a result of LV rupture. The biglycan null mice also exhibited aggravated LV dilation and worse LV function at 21 days post-MI [127]. Ex vivo measurements demonstrated that LV tensile strength was compromised, attributed to impaired collagen matrix organization [127]. Colocalization of biglycan with collagen type I in the infarct region implicates biglycan in regulation of collagen deposition and appropriate cross-linking [130]. Therefore, biglycan is required for stable collagen assembly and scar formation to preserve LV function. Compared with wild-type, biglycan null cardiac fibroblasts exhibited enhanced proliferation and increased TGF- $\beta$ receptor II expression and Smad 2 phosphorylation. Biglycan deficiency increased fibroblast transformation to myofibroblast, characterized by increased incorporation of $\alpha$-SMA into stress fibers, formation of focal adhesions, and contraction of collagen gels [80]. Neutralizing TGF- $\beta$ activity reversed the proproliferative and myofibroblastic phenotype in the absence of biglycan [80]. This suggests that biglycan regulation of fibroblast phenotype and function is dependent on TGF- $\beta$ signaling.

After MI, decorin deletion resulted in a wider distribution of collagen fibril sizes, resulting in a less organized and looser packed scar [126]. As such, decorin null mice exhibited a significant increase in scar size and right ventricular hypertrophy, as well as aggravated LV dilation and dysfunction [126]. These data demonstrate that decorin is required for proper collagen assembly, and that its absence leads to disorganized scar formation.

\section{Syndecans}

Syndecans are highly conserved transmembrane heparan sulfate proteoglycans and include four family members: syndecan-1 (syndecan), syndecan-2 (fibroglycan), syndecan3 ( $N$-syndecan), and syndecan-4 (ryudocan and amphiglycan). Structurally, syndecans are composed of an extracellular ectodomain, a transmembrane domain, and a short cytoplasmic domain. The ectodomain can be shed from cells and become a soluble form, which is the reason why syndecans have been occasionally considered matricellular proteins [29, 96]. Syndecans bind to a wide range of ECM proteins, growth factors, chemokines, and anticoagulant proteins by heparan sulfate glycosaminoglycan chains, playing critical roles in regulation of tissue injury and repair [11].

Following MI in experimental animals, syndecan-1 expression in the LV is upregulated at $24 \mathrm{~h}$, peaks at 7 days and declines thereafter [119]. Syndecan-1 deletion leads to adverse LV remodeling and dysfunction, accompanied by increased inflammation and activity of MMP-2 and MMP-9, decreased tissue transglutaminase activity, as well as increased collagen fragments and disorganization in mice subjected to MI [119]. In concordance, adenoviral gene expression of syndecan-1 rescued the effects observed in the absence of syndecan- 1 . These data suggest that increased syndecan-1 after MI protects from excessive inflammation and adverse infarct remodeling. A recent study showed that increased serum concentration of soluble syndecan-1 after MI was due to its increased expression in the infarcted myocardium [56].

Elevated plasma syndecan-4 levels in MI patients and the existence of syndecan-4 in the infarct region attracted research interest in investigating its role in MI-induced LV remodeling $[52,57]$. Syndecan-4 null mice do not show morphological and functional cardiac phenotype changes under normal conditions [75]. However, syndecan-4 deletion results in worse LV function and increased cardiac rupture and mortality. The potential mechanisms are associated with reduced inflammation, impaired granulation tissue formation, and decreased ECM deposition in the infarct region [75]. In vitro, syndecan-4 deficiency results in inhibition of fibronectininduced, but not TGF- $\beta 1$-induced, fibroblast differentiation into myofibroblasts. The shed form of syndecan- 4 acts as a 
dominant-negative inhibitor of endogenous syndecan-4 signaling. Accordingly, overexpression of the syndecan- 4 shed form mimics the effects observed when syndecan- 4 is deleted [75]. In summary, both syndecan- 1 and syndecan-4 exert protective roles in the MI setting by containing the inflammatory reaction and modulating ECM deposition.

\section{Vitronectin}

Vitronectin is an adhesive glycoprotein with multiple functions including blood coagulation, complement activation, binding to proteoglycans, and modifying the ECM [92]. In addition, vitronectin regulates cell differentiation, proliferation, migration, and morphogenesis [136]. Vitronectin can bind to a number of ligands/receptors, such as the urokinase receptor, integrin type cell adhesion receptors, growth factors, proteoglycans, plasminogen activator inhibitor, and high molecular weight kininogen $[72,92,136]$. The urokinase receptor regulates monocyte adhesion by direct binding to vitronectin, indicating a key role of vitronectin in regulating inflammation [77]. Plasma vitronectin concentration is elevated in patients with coronary artery diseases, showing a positive correlation with the extent of disease [26]. Another clinical trial showed that a higher percentage of patients with baseline vitronectin of $\geq 49.7 \mu \mathrm{g} / \mathrm{mL}$ had major adverse cardiovascular events (e.g., death, MI, or urgent revascularization) than patients with vitronectin of $<49.7 \mu \mathrm{g} / \mathrm{mL}$ at 30 days [21]. Moreover, when baseline variables not predictive of major adverse cardiovascular event (e.g., troponin positive, history of congestive heart failure, diabetes, history of hypertension, and smoking status) were excluded from the multivariate model, only baseline vitronectin of $\geq 49.7 \mu \mathrm{g} / \mathrm{mL}$ and history of MI remained [21]. This indicates that vitronectin may serve as an independent predictor of adverse cardiovascular outcomes following acute stenting.

\section{Matricryptins}

Matricryptins, biologically active fragments of the ECM, are generated from various mechanisms including enzymatic degradation, protein multimerization, absorption, cell-mediated mechanical forces, and denaturation [68]. Matricyrptins can be generated from any protein found in the extracellular space. Matricryptins regulate cell migration, proliferation, differentiation, morphogenesis, survival, ECM assembly, angiogenesis, tissue repair, and the inflammatory reaction [68, 94]. For example, neutrophils exert chemotaxis to fragments of collagen type IV [101]. Conversely, a matricryptin peptide from the $\alpha 3$ chain of collagen IV suppresses neutrophil activation [81]. MMP- 9 cleaves the $\alpha 3$ chain of collagen type IV to produce tumstatin, which inhibits angiogenesis [36]. In addition, MMPs are reported to cleave collagen IV, generating both anti- and pro-angiogenic fragments [13]. These reports

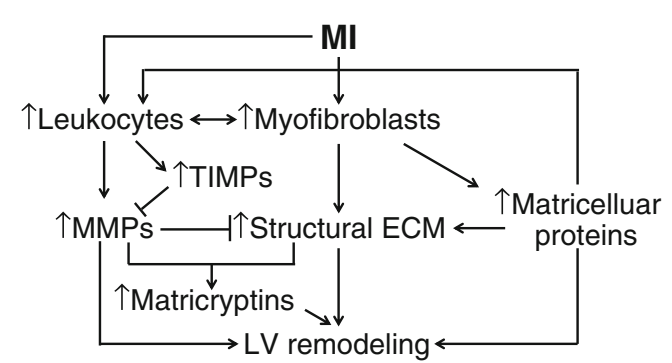

Fig. 2 The mechanisms of ECM regulation of LV remodeling post-MI. Following MI, increased myofibroblasts secrete abundant ECM proteins. Structural ECM mainly constitutes the reparative scar. MMPs primarily derived from leukocytes degrade ECM constituents and suppress ECM synthesis, which, in turn, is inhibited by TIMPs. Nonstructural matricellular proteins modulate leukocyte infiltration and function and affect structural ECM assembly. In addition, matricryptins, biologically active fragments of ECM, are formed by MMP degradation of ECM to influence several aspects of LV remodeling

suggest that collagen peptides have key biological activity in regulating post-MI LV remodeling. In the post-MI setting, endostatin, a matricriptin generated from collagen type XVIII, is elevated, and neutralization of endostatin exacerbates LV remodeling and dysfunction [45].

Fibronectin fragments stimulate monocyte migration and cause a positive feedback loop by increasing MMP production [99]. In addition, macrophages activated with fibronectin fragments enhance the survival of injured cardiac myocytes [113]. Degradation of laminin by neutrophil elastase generates fragments that are chemotactic for neutrophils, thus establishing a positive feedback loop for neutrophil recruitment [84]. Laminin $\alpha 1$ fragment stimulates macrophage expression of MMP-9, and laminin $\alpha 5$ peptide is reported to induce a wide range of cytokines in macrophages leading to a chemotactic response $[1,27]$. These data indicate that laminin and its fragments may play important roles in the inflammatory response post-MI. Research has just scratched the surface of matricryptin roles in the post-MI LV.

\section{Future directions}

Myofibroblasts, as the major source of ECM, are indispensable to appropriate cardiac repair post-MI. Controlling

Table 3 Areas of research for future directions

1. Fibroblast and myofibroblast post-MI phenotypes, as spatial and temporal variations in phenotypes may explain functional differences in LV remodeling responses

2. Expression patterns and roles of the multitude of MMPs not yet studied

3. Identification and characterization of fragments derived from ECM and non-ECM substrates

4. Expression patterns and roles of ECM constituents

$M I$ myocardial infarction, $L V$ left ventricle, $M M P S$ matrix metalloproteinases, $E C M$ extracellular matrix 
myofibroblast activation and function may stimulate proper wound healing response, thus attenuating adverse or excessive LV remodeling and preserving LV function. Balanced structural ECM deposition and breakdown limits infarct expansion, LV aneurysm and rupture, and LV wall stiffness. This process is tightly regulated by MMP activity, which in turn is controlled by TIMPs. Nonstructural matricellular proteins modulate inflammation, angiogenesis, and scar formation by direct binding to cell surface receptors and matrix. The sophisticated ECM networks crosstalk with each other, with inflammatory cells and mediators, to coordinate cardiac repair process (Fig. 2) [29, 68].

Despite advances over the past two decades in understanding the mechanisms of LV remodeling post-MI, additional studies are still needed to further clarify several important aspects (Table 3). First, mapping the phenotypes of fibroblasts isolated from infarct hearts at different time points will provide clues to their roles in coordinating the ECM response. Second, the temporal and spatial expression, cellular source, and function of many MMPs after MI have not yet been studied. For example, of the 25 identified MMPs, the role of 16 MMPs in the MI setting is presently unknown. Third, a more inclusive list of MMP substrates may provide additional insights, particularly for the non-ECM molecules (e.g., cytokines and chemokines), activated or deactivated by MMPs [46]. This broadens the field of MMP activity that directly links with the inflammatory response. Proteomics strategies that target inflammatory mediators and ECM can provide a more thorough and high throughput identification of novel ECM and non-ECM substrates [20]. Moreover, the biological functions of the fragments derived from substrate cleavage need to be characterized. Finally, more information on the individual ECM constituents and their roles in the remodeling response is needed. There are likely hundreds of different ECM proteins in the post-MI LV. The individual roles as well as their functions as part of the entire remodeling response remain to be examined [68]. While in vitro experiments study the roles of individual component, additional knowledge regarding the interaction of various components in regulating remodeling in the context of the entire post-MI myocardium is needed. This will allow us to design inhibitors or agonists that have the best translational potential.

\section{Conclusions}

In conclusion, MI remains a major cause of congestive heart failure. The extent of MI-induced LV remodeling is greatly dependent on the ECM regulation. Elucidating how the ECM regulates this transition of MI to heart failure will identify novel intervention targets that may help to stimulate an optimal wound healing response.
Acknowledgments The authors acknowledge support from the American Heart Association 14SDG18860050 to LECB, from the Rapoport Foundation for Cardiovascular Research to RAL, from National Institutes of Health (NIH)/NIH Heart, Lung and Blood Institute HHSN 268201000036C (N01-HV-00244) for the San Antonio Cardiovascular Proteomics Center, R01 HL075360 and HL051971, and from the Biomedical Laboratory Research and Development Service of the Veterans Affairs Office of Research and Development Award 5I01BX000505 to MLL.

Open Access This article is distributed under the terms of the Creative Commons Attribution License which permits any use, distribution, and reproduction in any medium, provided the original author(s) and the source are credited.

\section{References}

1. Adair-Kirk TL, Atkinson JJ, Kelley DG, Arch RH, Miner JH, Senior RM (2005) A chemotactic peptide from laminin alpha 5 functions as a regulator of inflammatory immune responses via TNF alpha-mediated signaling. J Immunol 174(3):1621-1629

2. Arslan F, Smeets MB, Riem Vis PW, Karper JC, Quax PH, Bongartz LG, Peters JH, Hoefer IE, Doevendans PA, Pasterkamp G, de Kleijn DP (2011) Lack of fibronectin-EDA promotes survival and prevents adverse remodeling and heart function deterioration after myocardial infarction. Circ Res 108(5):582-592. doi:10.1161/ CIRCRESAHA. 110.224428

3. Blankenberg S, Rupprecht HJ, Poirier O, Bickel C, Smieja M, Hafner G, Meyer J, Cambien F, Tiret L (2003) Plasma concentrations and genetic variation of matrix metalloproteinase 9 and prognosis of patients with cardiovascular disease. Circulation 107(12): 1579-1585. doi:10.1161/01.CIR.0000058700.41738.12

4. Bornstein P (2009) Matricellular proteins: an overview. J Cell Commun Signal 3(3-4):163-165. doi:10.1007/s12079-009-0069-Z

5. Brown RD, Ambler SK, Mitchell MD, Long CS (2005) The cardiac fibroblast: therapeutic target in myocardial remodeling and failure. Annu Rev Pharmacol Toxicol 45:657-687. doi:10.1146/annurev. pharmtox.45.120403.095802

6. Bujak M, Frangogiannis NG (2007) The role of TGF-beta signaling in myocardial infarction and cardiac remodeling. Cardiovasc Res 74(2):184-195. doi:10.1016/j.cardiores.2006.10.002

7. Burstein B, Libby E, Calderone A, Nattel S (2008) Differential behaviors of atrial versus ventricular fibroblasts: a potential role for platelet-derived growth factor in atrial-ventricular remodeling differences. Circulation 117(13):1630-1641. doi:10.1161/ CIRCULATIONAHA.107.748053

8. Camelliti P, Borg TK, Kohl P (2005) Structural and functional characterisation of cardiac fibroblasts. Cardiovasc Res 65(1):40 51. doi:10.1016/j.cardiores.2004.08.020

9. Camp TM, Tyagi SC, Aru GM, Hayden MR, Mehta JL (2004) Doxycycline ameliorates ischemic and border-zone remodeling and endothelial dysfunction after myocardial infarction in rats. J Heart Lung Transplant 23(6):729-736

10. Caplan AI, Dennis JE (2006) Mesenchymal stem cells as trophic mediators. J Cell Biochem 98(5):1076-1084. doi:10.1002/jcb.20886

11. Carey DJ (1997) Syndecans: multifunctional cell-surface coreceptors. Biochem J 327(Pt 1):1-16

12. Carver W, Terracio L, Borg TK (1993) Expression and accumulation of interstitial collagen in the neonatal rat heart. Anat Rec 236(3):511-520. doi:10.1002/ar.1092360311

13. Chang C, Werb Z (2001) The many faces of metalloproteases: cell growth, invasion, angiogenesis and metastasis. Trends Cell Biol 11(11):S37-S43 
14. Chen S, Birk DE (2013) The regulatory roles of small leucine-rich proteoglycans in extracellular matrix assembly. Febs J 280(10): 2120-2137. doi:10.1111/febs. 12136

15. Chiao YA, Zamilpa R, Lopez EF, Dai Q, Escobar GP, Hakala K, Weintraub ST, Lindsey ML (2010) In vivo matrix metalloproteinase-7 substrates identified in the left ventricle postmyocardial infarction using proteomics. J Proteome Res 9(5):26492657. doi:10.1021/pr100147r

16. Cicoira M, Rossi A, Bonapace S, Zanolla L, Golia G, Franceschini L, Caruso B, Marino PN, Zardini P (2004) Independent and additional prognostic value of aminoterminal propeptide of type III procollagen circulating levels in patients with chronic heart failure. J Card Fail 10(5):403-411

17. Cleutjens JP, Kandala JC, Guarda E, Guntaka RV, Weber KT (1995) Regulation of collagen degradation in the rat myocardium after infarction. J Mol Cell Cardiol 27(6):1281-1292

18. Coker ML, Jolly JR, Joffs C, Etoh T, Holder JR, Bond BR, Spinale FG (2001) Matrix metalloproteinase expression and activity in isolated myocytes after neurohormonal stimulation. Am J Physiol Heart Circ Physiol 281(2):H543-H551

19. Daniels A, van Bilsen M, Goldschmeding R, van der Vusse GJ, van Nieuwenhoven FA (2009) Connective tissue growth factor and cardiac fibrosis. Acta Physiol (Oxf) 195(3):321-338. doi:10.1111/ j.1748-1716.2008.01936.x

20. de Castro Bras LE, Ramirez TA, DeLeon-Pennell KY, Chiao YA, Ma Y, Dai Q, Halade GV, Hakala K, Weintraub ST, Lindsey ML (2013) Texas 3-step decellularization protocol: looking at the cardiac extracellular matrix. J Proteomics 86:43-52. doi:10.1016/j.jprot. 2013.05.004

21. Derer W, Barnathan ES, Safak E, Agarwal P, Heidecke H, Mockel M, Gross M, Oezcelik C, Dietz R, Dechend R (2009) Vitronectin concentrations predict risk in patients undergoing coronary stenting. Circ Cardiovasc Interv 2(1):14-19. doi:10.1161/ CIRCINTERVENTIONS.108.795799

22. Dinh W, Bansemir L, Futh R, Nickl W, Stasch JP, Coll-Barroso M, Lapp H, Bufe A, Wolfertz J, Scheffold T, Lankisch M (2009) Increased levels of laminin and collagen type VI may reflect early remodelling in patients with acute myocardial infarction. Acta Cardiol 64(3):329-334

23. Douglas T, Heinemann S, Bierbaum S, Scharnweber D, Worch H (2006) Fibrillogenesis of collagen types I, II, and III with small leucine-rich proteoglycans decorin and biglycan. Biomacromolecules 7(8):2388-2393. doi:10.1021/bm0603746

24. Ducharme A, Frantz S, Aikawa M, Rabkin E, Lindsey M, Rohde LE, Schoen FJ, Kelly RA, Werb Z, Libby P, Lee RT (2000) Targeted deletion of matrix metalloproteinase- 9 attenuates left ventricular enlargement and collagen accumulation after experimental myocardial infarction. J Clin Invest 106(1):55-62. doi:10.1172/JCI8768

25. Dumic J, Dabelic S, Flogel M (2006) Galectin-3: an open-ended story. Biochim Biophys Acta 1760(4):616-635. doi:10.1016/j. bbagen.2005.12.020

26. Ekmekci H, Sonmez H, Ekmekci OB, Ozturk Z, Domanic N, Kokoglu E (2002) Plasma vitronectin levels in patients with coronary atherosclerosis are increased and correlate with extent of disease. J Thromb Thrombolysis 14(3):221-225

27. Faisal Khan KM, Laurie GW, McCaffrey TA, Falcone DJ (2002) Exposure of cryptic domains in the alpha 1-chain of laminin-1 by elastase stimulates macrophages urokinase and matrix metalloproteinase-9 expression. J Biol Chem 277(16):1377813786. doi:10.1074/jbc.M111290200

28. Fligny C, Duffield JS (2013) Activation of pericytes: recent insights into kidney fibrosis and microvascular rarefaction. Curr Opin Rheumatol 25(1):78-86. doi:10.1097/BOR.0b013e32835b656b

29. Frangogiannis NG (2012) Matricellular proteins in cardiac adaptation and disease. Physiol Rev 92(2):635-688. doi:10.1152/physrev. 00008.2011
30. Frey H, Schroeder N, Manon-Jensen T, Iozzo RV, Schaefer L (2013) Biological interplay between proteoglycans and their innate immune receptors in inflammation. Febs J 280(10):2165-2179. doi: $10.1111 /$ febs. 12145

31. Friedenstein AJ, Deriglasova UF, Kulagina NN, Panasuk AF, Rudakowa SF, Luria EA, Ruadkow IA (1974) Precursors for fibroblasts in different populations of hematopoietic cells as detected by the in vitro colony assay method. Exp Hematol 2(2):83-92

32. Fukuda T, Yoshida N, Kataoka Y, Manabe R, Mizuno-Horikawa Y, Sato M, Kuriyama K, Yasui N, Sekiguchi K (2002) Mice lacking the EDB segment of fibronectin develop normally but exhibit reduced cell growth and fibronectin matrix assembly in vitro. Cancer Res 62(19):5603-5610

33. Gittenberger-de Groot AC, Vrancken Peeters MP, Mentink MM, Gourdie RG, Poelmann RE (1998) Epicardium-derived cells contribute a novel population to the myocardial wall and the atrioventricular cushions. Circ Res 82(10):1043-1052

34. Go AS, Mozaffarian D, Roger VL, Benjamin EJ, Berry JD, Blaha MJ, Dai S, Ford ES, Fox CS, Franco S, Fullerton HJ, Gillespie C, Hailpern SM, Heit JA, Howard VJ, Huffman MD, Judd SE, Kissela BM, Kittner SJ, Lackland DT, Lichtman JH, Lisabeth LD, Mackey RH, Magid DJ, Marcus GM, Marelli A, Matchar DB, McGuire DK, Mohler ER, 3rd, Moy CS, Mussolino ME, Neumar RW, Nichol G, Pandey DK, Paynter NP, Reeves MJ, Sorlie PD, Stein J, Towfighi A, Turan TN, Virani SS, Wong ND, Woo D, Turner MB (2013) Heart Disease and Stroke Statistics-2014 Update: A Report From the American Heart Association. Circulation. doi:10.1161/ 01.cir.0000441139.02102.80

35. Gondokaryono SP, Ushio H, Niyonsaba F, Hara M, Takenaka H, Jayawardana ST, Ikeda S, Okumura K, Ogawa H (2007) The extra domain A of fibronectin stimulates murine mast cells via toll-like receptor 4. J Leukoc Biol 82(3):657-665. doi:10.1189/jlb.1206730

36. Hamano Y, Zeisberg M, Sugimoto H, Lively JC, Maeshima Y, Yang C, Hynes RO, Werb Z, Sudhakar A, Kalluri R (2003) Physiological levels of tumstatin, a fragment of collagen IV alpha3 chain, are generated by MMP-9 proteolysis and suppress angiogenesis via alphaV beta3 integrin. Cancer Cell 3(6):589-601

37. Hammoud L, Lu X, Lei M, Feng Q (2011) Deficiency in TIMP-3 increases cardiac rupture and mortality post-myocardial infarction via EGFR signaling: beneficial effects of cetuximab. Basic Res Cardiol 106(3):459-471. doi:10.1007/s00395-010-0147-7

38. Hinz B (2006) Masters and servants of the force: the role of matrix adhesions in myofibroblast force perception and transmission. Eur $\mathrm{J}$ Cell Biol 85(3-4):175-181. doi:10.1016/j.ejcb.2005.09.004

39. Hinz B, Celetta G, Tomasek JJ, Gabbiani G, Chaponnier C (2001) Alpha-smooth muscle actin expression upregulates fibroblast contractile activity. Mol Biol Cell 12(9):2730-2741

40. Hinz B, Gabbiani G, Chaponnier C (2002) The NH2-terminal peptide of alpha-smooth muscle actin inhibits force generation by the myofibroblast in vitro and in vivo. J Cell Biol 157(4):657-663. doi:10.1083/jcb. 200201049

41. Hinz B, Phan SH, Thannickal VJ, Galli A, Bochaton-Piallat ML, Gabbiani G (2007) The myofibroblast: one function, multiple origins. Am J Pathol 170(6):1807-1816. doi:10.2353/ajpath.2007.070112

42. Hinz B, Pittet P, Smith-Clerc J, Chaponnier C, Meister JJ (2004) Myofibroblast development is characterized by specific cell-cell adherens junctions. Mol Biol Cell 15(9):4310-4320. doi:10.1091/ mbc.E04-05-0386

43. Ignotz RA, Massague J (1986) Transforming growth factor-beta stimulates the expression of fibronectin and collagen and their incorporation into the extracellular matrix. J Biol Chem 261(9): $4337-4345$

44. Ikonomidis JS, Hendrick JW, Parkhurst AM, Herron AR, Escobar PG, Dowdy KB, Stroud RE, Hapke E, Zile MR, Spinale FG (2005) Accelerated LV remodeling after myocardial infarction in TIMP-1deficient mice: effects of exogenous MMP inhibition. Am J Physiol 
Heart Circ Physiol 288(1):H149-H158. doi:10.1152/ajpheart. 00370.2004

45. Isobe K, Kuba K, Maejima Y, Suzuki J, Kubota S, Isobe M (2010) Inhibition of endostatin/collagen XVIII deteriorates left ventricular remodeling and heart failure in rat myocardial infarction model. Circ J 74(1):109-119

46. Iyer RP, Patterson NL, Fields GB, Lindsey ML (2012) The history of matrix metalloproteinases: milestones, myths, and misperceptions. Am J Physiol Heart Circ Physiol 303(8):H919-H930. doi: 10.1152/ajpheart.00577.2012

47. Joyner AL, Zervas M (2006) Genetic inducible fate mapping in mouse: establishing genetic lineages and defining genetic neuroanatomy in the nervous system. Dev Dyn 235(9):2376-2385. doi: $10.1002 /$ dvdy.20884

48. Kandalam V, Basu R, Abraham T, Wang X, Awad A, Wang W, Lopaschuk GD, Maeda N, Oudit GY, Kassiri Z (2010) Early activation of matrix metalloproteinases underlies the exacerbated systolic and diastolic dysfunction in mice lacking TIMP3 following myocardial infarction. Am J Physiol Heart Circ Physiol 299(4): H1012-H1023. doi:10.1152/ajpheart.00246.2010

49. Kandalam V, Basu R, Abraham T, Wang X, Soloway PD, Jaworski DM, Oudit GY, Kassiri Z (2010) TIMP2 deficiency accelerates adverse post-myocardial infarction remodeling because of enhanced MT1-MMP activity despite lack of MMP2 activation. Circ Res 106(4):796-808. doi:10.1161/CIRCRESAHA.109.209189

50. Keene DR, San Antonio JD, Mayne R, McQuillan DJ, Sarris G, Santoro SA, Iozzo RV (2000) Decorin binds near the C terminus of type I collagen. J Biol Chem 275(29):21801-21804. doi:10.1074/ jbc.C000278200

51. Kelly D, Khan S, Cockerill G, Ng LL, Thompson M, Samani NJ, Squire IB (2008) Circulating stromelysin-1 (MMP-3): a novel predictor of LV dysfunction, remodelling and all-cause mortality after acute myocardial infarction. Eur J Heart Fail 10(2):133-139. doi:10. 1016/j.ejheart.2007.12.009

52. Kojima T, Takagi A, Maeda M, Segawa T, Shimizu A, Yamamoto K, Matsushita T, Saito H (2001) Plasma levels of syndecan-4 (ryudocan) are elevated in patients with acute myocardial infarction. Thromb Haemost 85(5): 793-799

53. Koskivirta I, Kassiri Z, Rahkonen O, Kiviranta R, Oudit GY, McKee TD, Kyto V, Saraste A, Jokinen E, Liu PP, Vuorio E, Khokha R (2010) Mice with tissue inhibitor of metalloproteinases 4 (Timp4) deletion succumb to induced myocardial infarction but not to cardiac pressure overload. J Biol Chem 285(32):2448724493. doi:10.1074/jbc.M110.136820

54. Kovacic JC, Mercader N, Torres M, Boehm M, Fuster V (2012) Epithelial-to-mesenchymal and endothelial-to-mesenchymal transition: from cardiovascular development to disease. Circulation 125(14):1795-1808. doi:10.1161/CIRCULATIONAHA.111. 040352

55. Lajiness JD, Conway SJ (2013) Origin, development, and differentiation of cardiac fibroblasts. J Mol Cell Cardiol. doi:10.1016/j. yjmcc.2013.11.003

56. Lei J, Xue SN, Wu W, Zhou SX, Zhang YL, Yuan GY, Wang JF (2012) Increased level of soluble syndecan-1 in serum correlates with myocardial expression in a rat model of myocardial infarction. Mol Cell Biochem 359(1-2):177-182. doi:10.1007/s11010-0111012-1

57. Li J, Brown LF, Laham RJ, Volk R, Simons M (1997) Macrophagedependent regulation of syndecan gene expression. Circ Res 81(5): 785-796

58. Liao YF, Gotwals PJ, Koteliansky VE, Sheppard D, Van De Water L (2002) The EIIIA segment of fibronectin is a ligand for integrins alpha 9beta 1 and alpha 4beta 1 providing a novel mechanism for regulating cell adhesion by alternative splicing. J Biol Chem 277(17):14467-14474. doi:10.1074/ jbc.M201100200
59. Lin M, Jackson P, Tester AM, Diaconu E, Overall CM, Blalock JE, Pearlman E (2008) Matrix metalloproteinase-8 facilitates neutrophil migration through the corneal stromal matrix by collagen degradation and production of the chemotactic peptide Pro-Gly-Pro. Am J Pathol 173(1):144-153. doi:10.2353/ajpath.2008.080081

60. Lindsey ML, Escobar GP, Mukherjee R, Goshorn DK, Sheats NJ, Bruce JA, Mains IM, Hendrick JK, Hewett KW, Gourdie RG, Matrisian LM, Spinale FG (2006) Matrix metalloproteinase-7 affects connexin-43 levels, electrical conduction, and survival after myocardial infarction. Circulation 113(25):2919-2928. doi:10. 1161/CIRCULATIONAHA.106.612960

61. Lindsey ML, Goshorn DK, Squires CE, Escobar GP, Hendrick JW, Mingoia JT, Sweterlitsch SE, Spinale FG (2005) Age-dependent changes in myocardial matrix metalloproteinase/tissue inhibitor of metalloproteinase profiles and fibroblast function. Cardiovasc Res 66(2):410-419. doi:10.1016/j.cardiores.2004.11.029

62. Lindsey ML, Yoshioka J, MacGillivray C, Muangman S, Gannon J, Verghese A, Aikawa M, Libby P, Krane SM, Lee RT (2003) Effect of a cleavage-resistant collagen mutation on left ventricular remodeling. Circ Res 93(3):238-245. doi:10.1161/01.RES.0000085580. 45279.60

63. Lindsey ML, Zamilpa R (2012) Temporal and spatial expression of matrix metalloproteinases and tissue inhibitors of metalloproteinases following myocardial infarction. Cardiovasc Ther 30(1):31-41. doi:10.1111/j.1755-5922.2010.00207.x

64. Lu L, Zhang JQ, Ramires FJ, Sun Y (2004) Molecular and cellular events at the site of myocardial infarction: from the perspective of rebuilding myocardial tissue. Biochem Biophys Res Commun 320(3):907-913. doi:10.1016/j.bbrc.2004.06.034

65. Luria EA, Panasyuk AF, Friedenstein AY (1971) Fibroblast colony formation from monolayer cultures of blood cells. Transfusion 11(6):345-349

66. Luther DJ, Thodeti CK, Shamhart PE, Adapala RK, Hodnichak C, Weihrauch D, Bonaldo P, Chilian WM, Meszaros JG (2012) Absence of type VI collagen paradoxically improves cardiac function, structure, and remodeling after myocardial infarction. Circ Res 110(6):851-856. doi:10.1161/CIRCRESAHA.111.252734

67. Ma Y, Chiao YA, Zhang J, Manicone AM, Jin YF, Lindsey ML (2012) Matrix metalloproteinase-28 deletion amplifies inflammatory and extracellular matrix responses to cardiac aging. Microsc Microanal 18(1):81-90. doi:10.1017/S1431927611012220

68. Ma Y, Halade GV, Lindsey ML (2012) Extracellular matrix and fibroblast communication following myocardial infarction. J Cardiovasc Transl Res 5(6):848-857. doi:10.1007/s12265-0129398-Z

69. Ma Y, Halade GV, Zhang J, Ramirez TA, Levin D, Voorhees A, Jin YF, Han HC, Manicone AM, Lindsey ML (2013) Matrix metalloproteinase-28 deletion exacerbates cardiac dysfunction and rupture after myocardial infarction in mice by inhibiting M2 macrophage activation. Circ Res 112(4):675-688. doi:10.1161/ CIRCRESAHA.111.300502

70. Ma Y, Yabluchanskiy A, Lindsey ML (2013) Neutrophil roles in left ventricular remodeling following myocardial infarction. Fibrogenesis Tissue Repair 6(1):11. doi:10.1186/ 1755-1536-6-11

71. Ma Y, Yabluchanskiy A, Lindsey ML (2013) Thrombospondin-1: the good, the bad, and the complicated. Circ Res 113(12):12721274. doi:10.1161/CIRCRESAHA.113.302749

72. Madsen CD, Sidenius N (2008) The interaction between urokinase receptor and vitronectin in cell adhesion and signalling. Eur J Cell Biol 87(8-9):617-629. doi:10.1016/j.ejcb.2008.02.003

73. Manicone AM, Birkland TP, Lin M, Betsuyaku T, van Rooijen N, Lohi J, Keski-Oja J, Wang Y, Skerrett SJ, Parks WC (2009) Epilysin (MMP-28) restrains early macrophage recruitment in Pseudomonas aeruginosa pneumonia. J Immunol 182(6):3866-3876. doi:10. 4049/jimmunol.0713949 
74. Martos R, Baugh J, Ledwidge M, O'Loughlin C, Conlon C, Patle A, Donnelly SC, McDonald K (2007) Diastolic heart failure: evidence of increased myocardial collagen turnover linked to diastolic dysfunction. Circulation 115(7):888-895. doi:10.1161/ CIRCULATIONAHA.106.638569

75. Matsui Y, Ikesue M, Danzaki K, Morimoto J, Sato M, Tanaka S, Kojima T, Tsutsui H, Uede T (2011) Syndecan-4 prevents cardiac rupture and dysfunction after myocardial infarction. Circ Res 108(11):1328-1339. doi:10.1161/CIRCRESAHA.110.235689

76. Matsumura S, Iwanaga S, Mochizuki S, Okamoto H, Ogawa S, Okada Y (2005) Targeted deletion or pharmacological inhibition of MMP-2 prevents cardiac rupture after myocardial infarction in mice. J Clin Invest 115(3):599-609. doi:10.1172/JCI22304

77. May AE, Schmidt R, Kanse SM, Chavakis T, Stephens RW, Schomig A, Preissner KT, Neumann FJ (2002) Urokinase receptor surface expression regulates monocyte adhesion in acute myocardial infarction. Blood 100(10):3611-3617. doi:10.1182/blood2002-03-0778

78. Mayr A, Klug G, Mair J, Streil K, Harrasser B, Feistritzer HJ, Jaschke W, Schocke M, Pachinger O, Metzler B (2013) Galectin3: relation to infarct scar and left ventricular function after myocardial infarction. Int J Cardiol 163(3):335-337. doi:10.1016/j.ijcard. 2012.06.087

79. McCurdy SM, Dai Q, Zhang J, Zamilpa R, Ramirez TA, Dayah T, Nguyen N, Jin YF, Bradshaw AD, Lindsey ML (2011) SPARC mediates early extracellular matrix remodeling following myocardial infarction. Am J Physiol Heart Circ Physiol 301(2):H497H505. doi:10.1152/ajpheart.01070.2010

80. Melchior-Becker A, Dai G, Ding Z, Schafer L, Schrader J, Young MF, Fischer JW (2011) Deficiency of biglycan causes cardiac fibroblasts to differentiate into a myofibroblast phenotype. J Biol Chem 286(19):17365-17375. doi:10.1074/jbc. M110.192682

81. Monboisse JC, Garnotel R, Bellon G, Ohno N, Perreau C, Borel JP, Kefalides NA (1994) The alpha 3 chain of type IV collagen prevents activation of human polymorphonuclear leukocytes. J Biol Chem 269(41):25475-25482

82. Morishita N, Kusachi S, Yamasaki S, Kondo J, Tsuji T (1996) Sequential changes in laminin and type IV collagen in the infarct zone-immunohistochemical study in rat myocardial infarction. Jpn Circ J 60(2):108-114

83. Murphy-Ullrich JE, Poczatek M (2000) Activation of latent TGFbeta by thrombospondin-1: mechanisms and physiology. Cytokine Growth Factor Rev 11(1-2):59-69

84. Mydel P, Shipley JM, Adair-Kirk TL, Kelley DG, Broekelmann TJ, Mecham RP, Senior RM (2008) Neutrophil elastase cleaves laminin-332 (laminin-5) generating peptides that are chemotactic for neutrophils. J Biol Chem 283(15):9513-9522. doi:10.1074/jbc. M706239200

85. Nagai Y, Lapiere CM, Gross J (1966) Tadpole collagenase. Preparation and purification. Biochemistry 5(10):3123-3130

86. Nakao A, Imamura T, Souchelnytskyi S, Kawabata M, Ishisaki A, Oeda E, Tamaki K, Hanai J, Heldin CH, Miyazono K, ten Dijke P (1997) TGF-beta receptor-mediated signalling through Smad2, Smad3 and Smad4. Embo J 16(17):5353-5362. doi:10.1093/ emboj/16.17.5353

87. Oka T, Xu J, Kaiser RA, Melendez J, Hambleton M, Sargent MA, Lorts A, Brunskill EW, Dorn GW 2nd, Conway SJ, Aronow BJ, Robbins J, Molkentin JD (2007) Genetic manipulation of periostin expression reveals a role in cardiac hypertrophy and ventricular remodeling. Circ Res 101(3):313-321. doi:10.1161/ CIRCRESAHA.107.149047

88. Papadopoulos DP, Moyssakis I, Makris TK, Poulakou M, Stavroulakis G, Perrea D, Votteas VE (2005) Clinical significance of matrix metalloproteinases activity in acute myocardial infarction. Eur Cytokine Netw 16(2):152-160
89. Patterson NL, Iyer RP, de Castro Bras LE, Li Y, Andrews TG, Aune GJ, Lange RA, Lindsey ML (2013) Using proteomics to uncover extracellular matrix interactions during cardiac remodeling. Proteomics: Clin Appl 7(7-8):516-527. doi:10.1002/prca. 201200100

90. Peterson JT, Li H, Dillon L, Bryant JW (2000) Evolution of matrix metalloprotease and tissue inhibitor expression during heart failure progression in the infarcted rat. Cardiovasc Res 46(2):307-315

91. Porter KE, Turner NA (2009) Cardiac fibroblasts: at the heart of myocardial remodeling. Pharmacol Ther 123(2):255-278. doi:10. 1016/j.pharmthera.2009.05.002

92. Preissner KT, Reuning U (2011) Vitronectin in vascular context: facets of a multitalented matricellular protein. Semin Thromb Hemost 37(4):408-424. doi:10.1055/s-0031-1276590

93. Reinecke H, Minami E, Poppa V, Murry CE (2004) Evidence for fusion between cardiac and skeletal muscle cells. Circ Res 94(6): e56-e60. doi:10.1161/01.RES.0000125294.04612.81

94. Ricard-Blum S, Ballut L (2011) Matricryptins derived from collagens and proteoglycans. Front Biosci (Landmark Ed) 16: 674-697

95. Romanic AM, Burns-Kurtis CL, Gout B, Berrebi-Bertrand I, Ohlstein EH (2001) Matrix metalloproteinase expression in cardiac myocytes following myocardial infarction in the rabbit. Life Sci 68(7):799-814

96. Sage EH (2001) Regulation of interactions between cells and extracellular matrix: a command performance on several stages. J Clin Invest 107(7):781-783. doi:10.1172/JCI12683

97. Sato Y, Kataoka K, Matsumori A, Sasayama S, Yamada T, Ito H, Takatsu Y (1997) Measuring serum aminoterminal type III procollagen peptide, 7S domain of type IV collagen, and cardiac troponin $\mathrm{T}$ in patients with idiopathic dilated cardiomyopathy and secondary cardiomyopathy. Heart 78(5):505-508

98. Sawicki G, Leon H, Sawicka J, Sariahmetoglu M, Schulze CJ, Scott PG, Szczesna-Cordary D, Schulz R (2005) Degradation of myosin light chain in isolated rat hearts subjected to ischemia-reperfusion injury: a new intracellular target for matrix metalloproteinase-2. Circulation 112(4):544-552. doi:10.1161/CIRCULATIONAHA. 104.531616

99. Schedin P, Strange R, Mitrenga T, Wolfe P, Kaeck M (2000) Fibronectin fragments induce MMP activity in mouse mammary epithelial cells: evidence for a role in mammary tissue remodeling. $\mathrm{J}$ Cell Sci 113(Pt 5):795-806

100. Schoneveld AH, Hoefer I, Sluijter JP, Laman JD, de Kleijn DP, Pasterkamp G (2008) Atherosclerotic lesion development and Toll like receptor 2 and 4 responsiveness. Atherosclerosis 197(1):95104. doi:10.1016/j.atherosclerosis.2007.08.004

101. Senior RM, Hinek A, Griffin GL, Pipoly DJ, Crouch EC, Mecham RP (1989) Neutrophils show chemotaxis to type IV collagen and its $7 \mathrm{~S}$ domain and contain a $67 \mathrm{kD}$ type IV collagen binding protein with lectin properties. Am J Respir Cell Mol Biol 1(6):479-487. doi:10.1165/ajrcmb/1.6.479

102. Serini G, Bochaton-Piallat ML, Ropraz P, Geinoz A, Borsi L, Zardi L, Gabbiani G (1998) The fibronectin domain ED-A is crucial for myofibroblastic phenotype induction by transforming growth factor-beta1. J Cell Biol 142(3):873-881

103. Shamhart PE, Meszaros JG (2010) Non-fibrillar collagens: key mediators of post-infarction cardiac remodeling? J Mol Cell Cardiol 48(3):530-537. doi:10.1016/j.yjmcc.2009.06.017

104. Shimazaki M, Nakamura K, Kii I, Kashima T, Amizuka N, Li M, Saito M, Fukuda K, Nishiyama T, Kitajima S, Saga Y, Fukayama M, Sata M, Kudo A (2008) Periostin is essential for cardiac healing after acute myocardial infarction. J Exp Med 205(2):295-303. doi: 10.1084/jem.20071297

105. Silzle T, Randolph GJ, Kreutz M, Kunz-Schughart LA (2004) The fibroblast: sentinel cell and local immune modulator in tumor tissue. Int J Cancer 108(2):173-180. doi:10.1002/ijc.11542 
106. Souders CA, Bowers SL, Baudino TA (2009) Cardiac fibroblast: the renaissance cell. Circ Res 105(12):1164-1176. doi:10.1161/ CIRCRESAHA.109.209809

107. Squire IB, Evans J, Ng LL, Loftus IM, Thompson MM (2004) Plasma MMP-9 and MMP-2 following acute myocardial infarction in man: correlation with echocardiographic and neurohumoral parameters of left ventricular dysfunction. J Card Fail 10(4):328-333

108. Suzuki N, Yokoyama F, Nomizu M (2005) Functional sites in the laminin alpha chains. Connect Tissue Res 46(3):142-152. doi:10. 1080/03008200591008527

109. Szadkowska I, Wlazel RN, Migala M, Bajon-Laskowska K, Szadkowski K, Zielinska M, Paradowski M, Pawlicki L (2013) The association between galectin-3 and occurrence of reinfarction early after first myocardial infarction treated invasively. Biomarkers 18(8):655-659. doi:10.3109/1354750X.2013.840801

110. Tamaoki M, Imanaka-Yoshida K, Yokoyama K, Nishioka T, Inada H, Hiroe M, Sakakura T, Yoshida T (2005) Tenascin-C regulates recruitment of myofibroblasts during tissue repair after myocardial injury. Am J Pathol 167(1):71-80. doi:10.1016/S0002-9440(10)62954-9

111. Tomasek JJ, Gabbiani G, Hinz B, Chaponnier C, Brown RA (2002) Myofibroblasts and mechano-regulation of connective tissue remodelling. Nat Rev Mol Cell Biol 3(5):349-363. doi:10.1038/nrm809

112. Trial J, Cieslik KA, Haudek SB, Duerrschmid C, Entman ML (2013) Th1/M1 conversion to th $2 / \mathrm{m} 2$ responses in models of inflammation lacking cell death stimulates maturation of monocyte precursors to fibroblasts. Front Immunol 4:287. doi:10.3389/fimmu. 2013.00287

113. Trial J, Rossen RD, Rubio J, Knowlton AA (2004) Inflammation and ischemia: macrophages activated by fibronectin fragments enhance the survival of injured cardiac myocytes. Exp Biol Med 229(6):538-545

114. Tsai TH, Sung PH, Chang LT, Sun CK, Yeh KH, Chung SY, Chua S, Chen YL, Wu CJ, Chang HW, Ko SF, Yip HK (2012) Value and level of galectin-3 in acute myocardial infarction patients undergoing primary percutaneous coronary intervention. $\mathrm{J}$ Atheroscler Thromb 19(12):1073-1082

115. Turner NA, Porter KE (2013) Function and fate of myofibroblasts after myocardial infarction. Fibrogenesis Tissue Repair 6(1):5. doi: 10.1186/1755-1536-6-5

116. van den Borne SW, Cleutjens JP, Hanemaaijer R, Creemers EE, Smits JF, Daemen MJ, Blankesteijn WM (2009) Increased matrix metalloproteinase- 8 and -9 activity in patients with infarct rupture after myocardial infarction. Cardiovasc Pathol 18(1):37-43. doi:10. 1016/j.carpath.2007.12.012

117. Van Wart HE, Birkedal-Hansen H (1990) The cysteine switch: a principle of regulation of metalloproteinase activity with potential applicability to the entire matrix metalloproteinase gene family. Proc Natl Acad Sci U S A 87(14):5578-5582

118. Vanhoutte D, Schellings M, Pinto Y, Heymans S (2006) Relevance of matrix metalloproteinases and their inhibitors after myocardial infarction: a temporal and spatial window. Cardiovasc Res 69(3): 604-613. doi:10.1016/j.cardiores.2005.10.002

119. Vanhoutte D, Schellings MW, Gotte M, Swinnen M, Herias V, Wild MK, Vestweber D, Chorianopoulos E, Cortes V, Rigotti A, Stepp MA, Van de Werf F, Carmeliet P, Pinto YM, Heymans S (2007) Increased expression of syndecan-1 protects against cardiac dilatation and dysfunction after myocardial infarction. Circulation 115(4): 475-482. doi:10.1161/CIRCULATIONAHA.106.644609

120. Verrecchia F, Chu ML, Mauviel A (2001) Identification of novel TGF-beta/Smad gene targets in dermal fibroblasts using a combined cDNA microarray/promoter transactivation approach. J Biol Chem 276(20):17058-17062. doi:10.1074/jbc.M100754200

121. Visse R, Nagase H (2003) Matrix metalloproteinases and tissue inhibitors of metalloproteinases: structure, function, and biochemistry. Circ Res 92(8):827-839. doi:10.1161/01.RES.0000070112. 80711.3D
122. Weber KT (1997) Monitoring tissue repair and fibrosis from a distance. Circulation 96(8):2488-2492

123. Weber KT, Sun Y, Tyagi SC, Cleutjens JP (1994) Collagen network of the myocardium: function, structural remodeling and regulatory mechanisms. J Mol Cell Cardiol 26(3):279-292. doi:10.1006/jmcc. 1994.1036

124. Weir RA, Clements S, Steedman T, Dargie HJ, McMurray JJ, Squire IB, Ng LL (2011) Plasma TIMP-4 predicts left ventricular remodeling after acute myocardial infarction. J Card Fail 17(6):465-471. doi:10.1016/j.cardfail.2011.02.002

125. Weir RA, Petrie CJ, Murphy CA, Clements S, Steedman T, Miller AM, McInnes IB, Squire IB, Ng LL, Dargie HJ, McMurray JJ (2013) Galectin-3 and cardiac function in survivors of acute myocardial infarction. Circ Heart Fail 6(3):492-498. doi:10.1161/ CIRCHEARTFAILURE.112.000146

126. Weis SM, Zimmerman SD, Shah M, Covell JW, Omens JH, Ross J Jr, Dalton N, Jones Y, Reed CC, Iozzo RV, McCulloch AD (2005) A role for decorin in the remodeling of myocardial infarction. Matrix Biol 24(4):313-324. doi:10.1016/j.matbio.2005.05.003

127. Westermann D, Mersmann J, Melchior A, Freudenberger T, Petrik C, Schaefer L, Lullmann-Rauch R, Lettau O, Jacoby C, Schrader J, Brand-Herrmann SM, Young MF, Schultheiss HP, Levkau B, Baba HA, Unger T, Zacharowski K, Tschope C, Fischer JW (2008) Biglycan is required for adaptive remodeling after myocardial infarction. Circulation 117(10):1269-1276. doi:10.1161/ CIRCULATIONAHA.107.714147

128. Xia Y, Dobaczewski M, Gonzalez-Quesada C, Chen W, Biernacka A, Li N, Lee DW, Frangogiannis NG (2011) Endogenous thrombospondin 1 protects the pressure-overloaded myocardium by modulating fibroblast phenotype and matrix metabolism. Hypertension 58(5):902-911. doi:10.1161/ HYPERTENSIONAHA.111.175323

129. Yabluchanskiy A, Ma Y, Iyer RP, Hall ME, Lindsey ML (2013) Matrix metalloproteinase-9: many shades of function in cardiovascular disease. Physiology (Bethesda) 28(6):391-403. doi:10.1152/ physiol.00029.2013

130. Yamamoto K, Kusachi S, Ninomiya Y, Murakami M, Doi M, Takeda K, Shinji T, Higashi T, Koide N, Tsuji T (1998) Increase in the expression of biglycan mRNA expression co-localized closely with that of type I collagen mRNA in the infarct zone after experimentally-induced myocardial infarction in rats. J Mol Cell Cardiol 30(9):1749-1756. doi:10.1006/jmcc.1998.0737

131. Yang RY, Rabinovich GA, Liu FT (2008) Galectins: structure, function and therapeutic potential. Expert Rev Mol Med 10:e17. doi:10.1017/S1462399408000719

132. Zamilpa R, Ibarra J, de Castro Bras LE, Ramirez TA, Nguyen N, Halade GV, Zhang J, Dai Q, Dayah T, Chiao YA, Lowell W, Ahuja SS, D'Armiento J, Jin YF, Lindsey ML (2012) Transgenic overexpression of matrix metalloproteinase-9 in macrophages attenuates the inflammatory response and improves left ventricular function post-myocardial infarction. J Mol Cell Cardiol 53(5):599-608. doi: 10.1016/j.yjmcc.2012.07.017

133. Zamilpa R, Lopez EF, Chiao YA, Dai Q, Escobar GP, Hakala K, Weintraub ST, Lindsey ML (2010) Proteomic analysis identifies in vivo candidate matrix metalloproteinase- 9 substrates in the left ventricle post-myocardial infarction. Proteomics 10(11):2214 2223. doi:10.1002/pmic. 200900587

134. Zeisberg EM, Kalluri R (2010) Origins of cardiac fibroblasts. Circ Res 107(11):1304-1312. doi:10.1161/CIRCRESAHA.110.231910

135. Zeisberg EM, Ma Q, Juraszek AL, Moses K, Schwartz RJ, Izumo S, $\mathrm{Pu}$ WT (2005) Morphogenesis of the right ventricle requires myocardial expression of Gata4. J Clin Invest 115(6):1522-1531. doi: 10.1172/JCI23769

136. Zhou A, Huntington JA, Pannu NS, Carrell RW, Read RJ (2003) How vitronectin binds PAI-1 to modulate fibrinolysis and cell migration. Nat Struct Biol 10(7):541-544. doi:10.1038/nsb943 